(Pryles et al., 1959), though it was thought to be $7 \%$ in one series (Virtanen et al., 1962). The method of catheterization which we have used has been widely and successfully employed in the catheterization of paraplegic patients, in whom the risk of infection is very high (McLeod et al., 1963). Though catheterization of the urinary bladder is undesirable for other reasons as well as the possible risk of infection, there are instances where it is indicated. One of these would be continuing doubt about the diagnosis of urinary tract infection in children after the examination of non-catheter specimens. The method described here seems to be a safe and practical one.

\section{Summary}

Non-catheter (bag or midstream specimen) and catheter specimens of urine from 68 children suspected to be suffering from infection of the renal tract have been compared. Accepting the catheter specimen predominantly as the indicator of urinary tract infection, it was concluded that 32 children $(47 \%)$ were suffering from pyelonephritis.

With the use of certain specified diagnostic criteria on single non-catheter specimens of urine $25(78 \%)$ of the infected cases were diagnosed positively. In the 68 cases there were only five (7\%) false-positives among the non-catheter specimens, suggest- ing that the criteria used reduce significantly the high incidence of false-positive results which tends to occur with random noncatheter specimens.

Means by which false-negative results can be avoided include a "re-examination" standard and consideration of urinary $\mathrm{pH}$.

A method of bladder catheterization in children with the use of a Polybactrin technique appears to be safe and can be used in cases where diagnoses cannot be readily established from non-catheter specimens.

J.W.M. wishes to thank the Royal Society for a grant for expenses, the M.R.C. for the provision of technical assistance, and Messrs. Calmic for supplies of Polybactrin G.U.

RBFERENCES

Ansell, J. (1962). 7. chron. Dis., 15, 675.

Braude, H., Forfar, J. O., Gould, J. C., and McLeod, J. W. (1967). Brit. med. Y., 4, 697

Gould, J. C."(1965) Brit. F. Urol., 37, 7.

McLeod, J. W., Mason, J. M., and Pilley, A. A. (1963). Lancet, 1, 292

Pryles, C. V., Atkin M. D., Morse, T. S., and Welch, K. J. (1959). Pediatrics, 24, 983. Pediatrics, 24, 983. Alkan, M K. (1961). Ibid., 27, 17. and Steg, N. L (1959). Ibid., 23, 441 .

Virtanen, S., Oksanen, T., and Peltunen, T. (1962). Ann. Paediat. Fenn. 8, 269.

\title{
"Clean Catch" Urines in the Newborn-Bacteriology and Cell Excretion Patterns in First Week of Life
}

\author{
GILLIAN CRUICKSHANK,* M.B., B.CH., D.C.H. ; ELIZABETH EDMOND, $†$ M.B., CH.B.
}

Brit. mod. Э., 1967, 4, 705-707

Urinary tract infection in the newborn may not be uncommon (Stansfeld, 1954, 1966 ; Lincoln and Winberg, 1964a; Smellie et al., 1964). Clinical signs mav be variable or absent, and diagnosis depends on the demonstration of a significant bacteriuria. However, in the absence of a reliable and simple method of collection of specimens diagnosis is difficult. Catheterization and suprapubic puncture are probably not acceptable as routine procedures (Pryles, 1965). The reliability of three supervised "clean catch" specimens of urine in the newborn has been assessed by bacteriological techniques, with particular reference to the problem of contamination. At the same time the urinary cell-excretion pattern in the first week of life was studied by means of a differential staining technique (Prescott and Brodie, 1964).

\section{Method}

Forty babies (21 male and 19 female) who were free from recognized infection and not receiving antibiotics were included in the study. Details of delivery and drug therapy in the mother were noted. A clean-catch specimen, personally supervised by one of us, was collected from each baby on the second, fourth, and sixth day of life. The buttocks and perineum were well cleansed with soap and water only, the labia were separated, but the foreskin was not retracted. The skin was dried with a sterile swab. The baby was supported with the

\footnotetext{
- Paediatric Registrar, Elsie Inglis Maternity Hospital, Edinburgh. Present appointment: Scientific Staff, Medical Research Council, Western General Hospital, Edinburgh.

t Registrar in Bacteriology. Central Microbiological Laboratory, Western General Hespital, Edinburgh.
}

thighs abducted, and any urine passed was collected directly into a sterile container, which was not allowed to come into contact with the baby's skin at any time. If no urine was passed within 20 minutes the baby was rewashed or the collection postponed until a more opportune moment. Urine specimens were discarded if there was a simultaneous bowel movement and further specimens collected only after rewashing.

The collected specimen was divided into two portions. One was refrigerated and transported to the bacteriological laboratory in a cooled vacuum flask. A maximum of four hours occurred between collection and plating. Quantitative bacteriological culture was carried out as described by Urquhart and Gould (1965). Blood agar and MacConkey plates were inoculated and incubated aerobically for 24 hours. The second portion was examined microscopically within two hours of collection. For staining, 2:7-diaminofluorene phloxine- $B$ was used as described by Prescott and Brodie (1964), thereby allowing differentiation of leucocytes and renal tubular cells. Examination of the uncentrifuged, well-shaken, and stained urine was carried out on an improved Neubauer counting-chamber, counting five squares and multiplying by two (Lawson and Hewstone, 1964).

\section{Results}

One hundred and twenty "clean catch" specimens were collected from the 40 babies. A total of 103 specimens $(86 \%)$ produced on culture a colony count of $10^{4}$ organisms per ml. or less, and 71 of these specimens $(59 \%)$ produced no growth on culture (Table I). If a level of $10^{5}$ organisms per $\mathrm{ml}$. is 
taken as significant of infection $86 \%$ of these specimens could be regarded as showing no evidence of infection.

Table II indicates how the 71 specimens producing no growth on culture were distributed. There were only five babies from whom all three specimens produced growth.

Bacteria were isolated from a total of 49 specimens (41\%). The distribution of species and viable count from these 49 was as shown in Table III. For the purpose of this Table, Staphylococcus albus, corynebacteria, and Streptococcus viridans are regarded as skin commensals, while Escherichia coli, nonlactose-fermenting coliforms, Proteus species, and enterococci are classed as potential pathogens.

Seventeen specimens produced counts greater than $10^{4}$ organisms per $\mathrm{ml}$. In seven of these skin commensal bacteria were present, suggesting an "unclean" specimen and indicating the necessity for repeating the examination. Ten specimens collected from seven babies produced a high count of potential pathogens in either pure or mixed culture.

TABlB I.-Distribution of Bacterial Counts in 120 Clean-catch Specimens

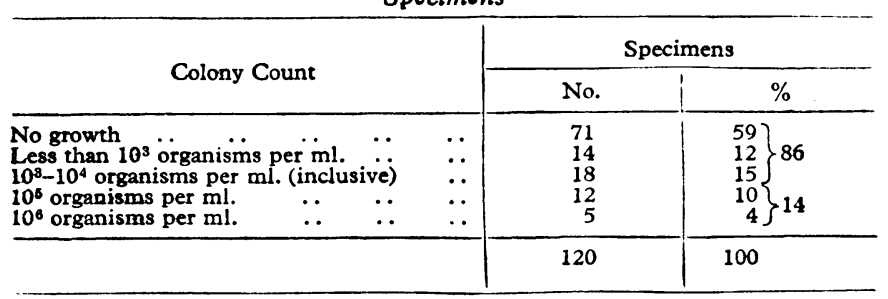

TablB II.-Incidence of "No Growth" Cultures Among 40 Babies

\begin{tabular}{|l|c|c|c}
\hline & No. of Babies & No. of Specimens \\
\hline "No growth" on 3 occasions $\ldots$ & $\ldots$ & 14 & 42 \\
"No growth" on 2 occasions. & $\ldots$ & 8 & 16 \\
\hline "No growth" on 1 occasion only & $\ldots$ & 13 & 13 \\
\hline
\end{tabular}

TABLE III.-Analysis of Organisms Obtained from Clean-catch Urines

\begin{tabular}{c|c|c|c|c|c} 
& & \multicolumn{4}{|c}{ Character of Isolate } \\
\cline { 2 - 5 } $\begin{array}{c}\text { Count } \\
\text { (orgs./ml.) }\end{array}$ & $\begin{array}{c}\text { Total } \\
\text { Specimens }\end{array}$ & $\begin{array}{c}\text { Pathogens } \\
\text { in Pure } \\
\text { Culture }\end{array}$ & $\begin{array}{c}\text { Pathogens } \\
\text { in Mixed } \\
\text { Culture }\end{array}$ & $\begin{array}{c}\text { Mixed } \\
\text { Pathogens } \\
\text { and } \\
\text { Commensals }\end{array}$ & $\begin{array}{c}\text { Commensals } \\
\text { in Pure } \\
\text { Culture }\end{array}$ \\
\hline $\begin{array}{c}\text { Less than } 10^{3} \\
10^{8}-10^{4}\end{array}$ & 14 & 2 & 1 & 8 & 3 \\
$10^{5}$ & 18 & 7 & 5 & 3 & 3 \\
$10^{8}$ & 5 & 4 & 3 & 4 & 1 \\
& 12 & 2 & 1 & 2 & 0 \\
\hline
\end{tabular}
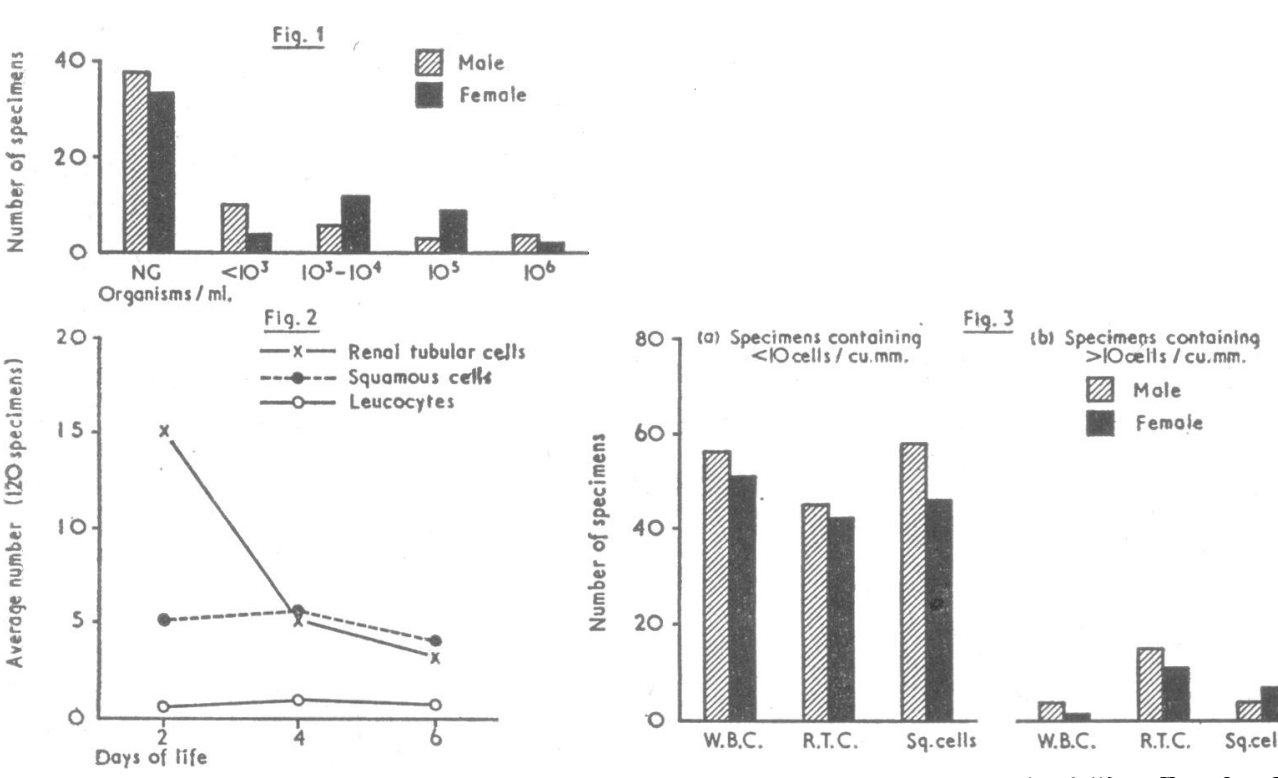

0.5 to 1.2 /cu. mm. The excretion of renal tubular cells shows a very different pattern, falling rapidly from a high average excretion rate of $14.9 / \mathrm{cu}$. $\mathrm{mm}$. on the second day to a low average value of 3 cells/cu. $\mathrm{mm}$. on the sixth day. These cells were easily distinguished from leucocytes by the peroxidasepositive stain.

Ninety-six per cent. of specimens contained fewer than 10 leucocytes per cu. mm. These were collected from 57 males and 51 females. Of the four specimens containing more than 10 leucocytes per cu. mm. two were associated with a high count of mixed organisms suggestive of contamination, and subsequent specimens contained a smaller number of cells. One specimen was associated with dehydration of the newborn, and the fourth specimen, with a high white cell excretion, produced no growth on culture.

There was no correlation of bacterial counts and cell counts in this series. This is shown in Table V, where the apparently high leucocyte count associated with bacterial counts greater than $10^{5} / \mathrm{ml}$. cannot be taken as significant in view of the small number involved (four), including one isolated count of 48 leucocytes per cu. mm. apparently associated with dehydration of the newborn.

The birth history and immediate postnatal progress of the babies were studied in relation to the renal tubular cell count. There were 19 babies showing one or more 
counts of more than 10 renal tubular cells per cu. mm. (range $12-40$ ). In 15 of these labour and the postnatal period were uneventful, and in four there was some complication. In the other 21 babies, none of whom produced specimens with high counts of renal tubular cells, there was a history of difficulty in delivery in four and a premature delivery in one.

Only nine $(8 \%)$ specimens contained more than 10 squamous cells per cu. mm. These were collected from nine babies (six females and three males). While this suggests some sex difference, total numbers are small. No significant sex difference was found in the excretion of renal tubular cells or leucocytes (Fig. 3).

TABLB V.-Relation of Cell Counts to Bacterial Counts

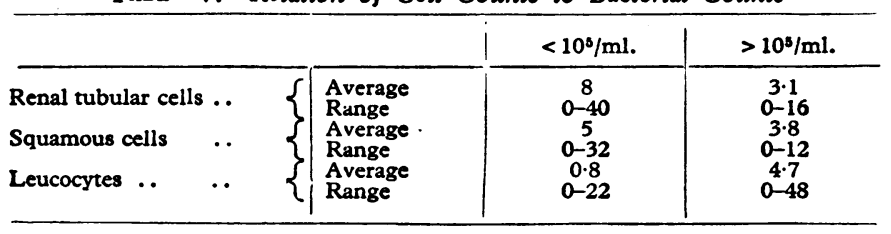

\section{Discussion}

The possibility of contamination in normally voided urine in the neonate has led to the use of catheterization (Pryles et al., 1961 ; McCarthy and Pryles, 1963) and suprapubic bladder aspiration (Pryles et al., 1959 ; Pryles, 1965 ; Nelson and Peters, 1965 ; Newman et al., 1967) for the collection of urine specimens for diagnostic purposes. The inherent dangers of both techniques indicated the necessity for the reassessment of the value of clean-catch specimens in this age group. The presence or absence of infection in the urinary tract has been assessed by consideration not only of the viable count but also of the species isolated in three consecutive clean-catch specimens. A viable count of $10^{5}$ organisms per ml. in a carefully collected midstream specimen is suggestive in the adult of infection in the urinary tract (Kass, 1957). There has been doubt about whether this criterion can apply in the neonate (Nelson and Peters, 1965). Houston (1963) suggested that $10^{6}$ organisms per $\mathrm{ml}$. or more is abnormal in neonates, but that with counts between $10^{5}$ and $10^{6}$ organisms per ml. confirmation of infection is required. In the present series $86 \%$ of specimens contained fewer than $10^{5}$ viable organisms per $\mathrm{ml}$. and $59 \%$ produced no growth. This compares favourably with the $31 \%$ of specimens producing no growth in the series of McCarthy and Pryles (1963), and is a considerable improvement on series collected by the bag method (Newman et al., 1967).

Urinary cell excretion in the neonate has been the subject of considerable study (Thomson, 1944 ; Houghton and Pears, 1957 ; James, 1959 ; Aas, 1961 ; Stansfeld, 1962 ; Lincoln and Winberg, 1964b; Lawson and Hewstone, 1964). In spite of this the number of leucocytes which may be accepted as normal remains in doubt. Lawson and Hewstone (1964) concluded that the finding of more than 10 white blood cells per cu. mm. on two or more occasions is abnormal. Lincoln and Winberg (1964b) fixed the highest acceptable normal number at $25 / \mathrm{cu}$. mm. in males and $50 / \mathrm{cu}$. $\mathrm{mm}$. in females. In this series, with the use of a differential staining technique, $96 \%$ of specimens contained fewer than 10 leucocytes per cu. $\mathrm{mm}$.

The high number of renal tubular cells excreted in the first few days of life has been noted by earlier workers (Craig, 1935 ; Thomson, 1944 ; Lawson and Hewstone, 1964). The similarity in size and shape of unstained renal tubular cells and leucocytes has in the past made differentiation difficult, but with the peroxidase-positive stain the particular pattern of renal tubular cell excretion emerges.

The high numbers present during the first few days of life have been ascribed to a period of rapid growth and shedding of cells from the renal tract epithelium at this time of life (Aas, 1961). Hypoxia and renal shut-down have also been suggested as causative factors (Jonsson, 1951 ; Halvorsen and Aas, 1962). This series produced no evidence to support the latter view.

\section{Conclusions}

Normally voided urine can be collected from the newborn without gross contamination by a careful clean-catch technique. When three specimens are collected from one patient contamination rather than infection is suggested by variation in the number and species of organisms isolated from specimen to specimen. Viable counts of less than $10^{5}$ organisms per ml. are usually due to contamination. Higher counts may also be due to contamination, and the presence of infection should be suspected only when counts of $10^{5}$ organisms per ml. or more of the same species are isolated in at least two consecutive specimens. This procedure is time-consuming, and personal supervision is essential, but it is without hazard to the infant. Only when every effort has been made to reach a conclusive diagnosis on the results of specimens collected in this way should other methods of urine collection be contemplated.

The newborn infant excretes a large number of renal tubular cells which may be confused with leucocytes if a differential stain is not used. The number of renal tubular cells excreted falls rapidly during the first week of life, while the excretion of leucocytes and squamous cells remains relatively constant. Leucocyte counts up to $10 / \mathrm{cu}$. $\mathrm{mm}$. can be accepted as normal in both sexes.

The value of using a simple differential stain, as described above, when carrying out microscopical examination of the urine is emphasized.

\section{Summary}

Three specimens of urine were collected from each of 40 babies on the second, fourth, and sixth day of life. A cleancatch technique was employed and shown to be a reliable method of urine sampling.

The cell excretion pattern during the first week of life was studied. Ninety-six per cent. of specimens contained fewer than 10 leucocytes per cu. mm. A high rate of excretion of renal tubular cells was observed during the first few days of life.

We would like to thank Professor J. O. Forfar and Dr. J. C. Gould for their helpful criticism and encouragement. Also we would like to acknowledge the co-operation of the nursery nursing staff at the Elsie Inglis Maternity Hospital, Edinburgh.

\section{REFERENCES}

Aas, K. (1961). Acta paediat. (Uppsala), 50, 361.

Craig, W. S. (1935). Arch. Dis. Childh., 10, 337

Halvorsen, S., and Aas, K. (1962). Acla Paediat. (Uppsala), 51, 417.

Houghton, B. J., and Pears, M. A. (1957). Brit. med. F., 1, 622.

Houston, 1. B. (1963). Arch. Dis. Childh., 38, 600.

James, U. (1959). Lancet, 2, 1001

Jonsson, B. (1951). Acta Paediat. (Uppsala), 40, 401.

Kass, E. H. (1957). Arch. intern. Med., 100, 709.

Lawson, J. S., and Hewstone. A. S. (1964). Arch. Dis. Childh., 39, 287.

Lincoln, K., and Winberg, J. (1964a). Acta Paediat. (Uppsala), 53, 307.

Lincol, (1964b) Ibid., 53, 447.

$\overline{M c C}$ arthy, J. M., and Pryles, C. V. (1963). Amer. 7. Dis. Child., 106, 473.

Nelson, J. D., and Peters, P. C. (1965). Pediatrics, 36, 132.

Newman, C. G. H., O'Neili, P., and Parker, A. (1967). Brit. med. J. $2,277$.

Prescott, L. F,, and Brodie, D. E. (1964). Lancet, 2, 940.

Pryles, C. V. (1965). Pediatrics, 36, 128

Alkin, M. D., Morse, T. S., and Welch, K. J. (1959). Ibid., 24, 983.

- Luders, D., and Alkan, M. K. (1961). Ibid., 27, 17.

Smellie, J. M., Hodson, C. J., Edwards, D., and Normand, I. C. S. (1964). Brit. med. 3., 2, 1222.

Stansfeld, J. M. (1954). Proc roy. Soc. Med., 47, 631.

Stansfeld, (1962). Arch. Dis Childh., 37, 257.

- (1966). Bril. med. F., 1, $\in 31$

Thomson, J. (1944). Arch. Dis. Childh., 19, 169.

Urquhart, G. E. D., and Gould, J. C. (1965). F. clin. Path., 18, 480. 